\title{
Ocena skutków regulacji rządowego projektu ustawy o zmianie ustawy o Radzie Ministrów oraz niektórych innych ustaw (druk sejmowy nr 3045) ${ }^{1}$
}

Impact assessment of rules of the governmental Bill on Amending the Act on the Council of Ministers and some other Acts (Sejm's paper no. 3045): The proposal of a provision that authorizes the Prime Minister to award for special rewards from a general reserve of the state budget seems to differ from an academic opinion that the feature of the general reserve is the lack of indication of its allocation in moment of its adoption. Non-specification of events, which may serve as prerequisites for awarding a special reward, and the inclusion of the regulation in the act, may raise some concerns. The bill may (in respect of taxation) differentiate between people who may be awarded with a special rewards by the Prime Minister, and people who may be awarded for their special achievements by ministers.

Keywords: public finances, reward, impact assessment, bill, the Council of Ministers, general reserve

Słowa kluczowe: finanse publiczne, nagroda, ocena skutków regulacji, projekt ustawy, Rada Ministrów, rezerwa ogólna

Ekspert ds. finansów publicznych BAS - monika.korolewska@sejm.gov.pl • https://orcid.org/0000-0002-6802-2367

\section{Zakres przedmiotowy ustawy}

Projekt ustawy przewiduje zmianę przepisów ustawy z 8 sierpnia 1996 r. o Radzie Ministrów. Ponadto projektowaną ustawą zmienia się również ustawę z 26 lipca 1991 r. o podatku dochodowym od osób fizycznych oraz ustawę z 12 marca 2004 r. o pomocy społecznej.

1 Opinia Ocena skutków regulacji rządowego projektu ustawy o zmianie ustawy o Radzie Ministrów oraz niektórych innych ustaw (druk sejmowy nr 3045) sporządzona 10 grudnia 2018 r. na zlecenie zastępcy Szefa Kancelarii Sejmu; BAS-WASiE 2835/18. 


\section{Podmioty, na które oddziałuje akt}

Projekt dotyczy:

- Prezesa Rady Ministrów - w związku z przyznaniem kompetencji do przyznawania nagród specjalnych,

- właściwych ministrów - z uwagi na obowiązek zasięgnięcia ich opinii w związku z przyznaniem przez Prezesa Rady Ministrów nagrody specjalnej.

\section{Celowość wprowadzenia aktu}

Celem projektowanej zmiany ustawy o Radzie Ministrów oraz niektórych innych ustaw jest umożliwienie Prezesowi Rady Ministrów przyznawania osobom fizycznym, w szczególnie uzasadnionych przypadkach (w tym za wybitne osiągnięcia naukowe, sportowe lub z zakresu kultury i ochrony dziedzictwa narodowego), po zasięgnięciu opinii właściwego ministra, nagród specjalnych ze środków rezerwy ogólnej budżetu państwa.

\section{Planowane środki (narzędzia i działania) realizacji celów}

Wnioskodawca projektu proponuje w ustawie o Radzie Ministrów dodać nowy artykuł. Przepis ten upoważniałby Prezesa Rady Ministrów do przyznawania osobom fizycznym, w szczególnie uzasadnionych przypadkach (w tym za wybitne osiągnięcia naukowe, sportowe lub z zakresu kultury i ochrony dziedzictwa narodowego), po zasięgnięciu opinii właściwego ministra, nagród specjalnych z rezerwy ogólnej budżetu państwa. Ponadto wnioskodawca proponuje zwolnić przyznaną przez Prezesa Rady Ministrów nagrodę specjalną z podatku dochodowego od osób fizycznych (poprzez dodanie nowego punktu w ust. 1 art. 21 ustawy o podatku dochodowym od osób fizycznych) oraz znieść obowiązek wliczania tej nagrody do dochodu służącego do ustalania prawa do świadczeń pieniężnych z pomocy społecznej (poprzez dodanie nowego punktu w ust. 4 art. 8 ustawy o pomocy społecznej).

Dokonując oceny zaplanowanych środków dla realizacji celu stawianego wobec przedłożonego projektu, należy zwrócić uwagę na kilka kwestii.

- W dodawanym nowym artykule do ustawy o Radzie Ministrów wskazuje się, że Prezes Rady Ministrów mógłby przyznać nagrodę specjalną osobie fizycznej z rezerwy ogólnej budżetu państwa, co może budzić zastrzeżenia. W myśl unormowań ustawy o finansach publicznych tworzenie rezerwy ogólnej w budżecie państwa jest obligatoryjne. Jest to rezerwa na nieprzewidziane wydatki i charakteryzuje się tym, że może być przeznaczona w toku wykonywania budżetu na jakiekolwiek rodzaje wydatków budżeto- 
wych ${ }^{2}$. Rezerwą ogólną dysponuje co do zasady Rada Ministrów, ale w wydanym rozporządzeniu ${ }^{3}$ Rada dokonała dekoncentracji tej kompetencji na rzecz Prezesa Rady Ministrów i Ministra Finansów. W świetle powyższego wydaje się, że nieuzasadnione jest proponowane w projekcie rozwiązanie wskazujące rezerwę ogólną budżetu państwa jako stałe źródło finansowania dla realizacji zadania, co prawda, o trudnym do ustalenia koszcie, ale jednak o trwałym charakterze. Wskazanie rezerwy ogólnej jako źródła sfinansowania realizacji konkretnego zadania miałoby ewentualnie swoje uzasadnienie, gdyby określało dokonanie wydatku z tej rezerwy w związku z przyjęciem przepisów regulujących realizację określonego zadania w trakcie toczącego się roku budżetowego. Tym samym środki finansowe na nagrody specjalne przyznawane przez Prezesa Rady Ministrów mogą pochodzić z rezerwy ogólnej budżetu państwa w roku 2019, natomiast w latach następnych powinny zostać ujęte albo w odpowiedniej części budżetowej albo w rezerwach celowych (jak ma to miejsce np. w przypadku środków finansowych na stypendia przyznawane przez Prezesa Rady Ministrów na podstawie przepisów ustawy o systemie oświaty).

- Projektowany przepis określa, że Prezes Rady Ministrów przyznawałby nagrodę specjalną w szczególnie uzasadnionych przypadkach. Może budzić wątpliwości, czy w tej sytuacji pojęcie szczególnie uzasadnionego przypadku jest odpowiednio dookreślone. Nasuwają się pytania: jakie kwestie należałoby oceniać, aby można było ustalić bezsprzecznie szczególnie uzasadniony przypadek i czy przesłanka do przyznania nagrody specjalnej nie będzie determinowana elementami subiektywnymi.

- Zastrzeżenia może budzić fakt, że wnioskodawca w projekcie nie ustalił przepisów określających sposób i metody postępowania przy przyznawaniu nagród specjalnych przez Prezesa Rady Ministrów ani nie zawarł przepisu kompetencyjnego umożliwiającego doprecyzowanie zasad i trybu przyznawania tych nagród w formie rozporządzenia. Należy zauważyć, że tego rodzaju regulacje zawierają obowiązujące przepisy nadające uprawnienia do przyznawania nagród za szczególne osiągnięcia ministrom. I tak przepisy ustawy o sporcie, w której regulowane są zagadnienia dotyczące nagród przyznawanych przez ministra właściwego do spraw kultury fizycznej za wybitne osiągnięcia sportowe, wskazują podstawowe zasady przyznawania tych nagród ${ }^{4}$, a w zakresie szczegółowej regulacji odsyłają do rozporządzenia wykonawcze-

2 Poza sytuacją, w której zostałyby zwiększone wydatki uprzednio zmniejszone w wyniku dokonania przeniesień wydatków.

3 Rozporządzenie Rady Ministrów z 27 lutego 2017 r. w sprawie dysponowania rezerwą ogólną budżetu państwa, Dz.U. poz. 500.

4 Zob. art. 34 ustawy z 25 czerwca 2010 r. o sporcie, t.j. Dz.U. 2018, poz. 1263, ze zm. 
go ${ }^{5}$. Podobnie czynią przepisy ustawy o organizowaniu i prowadzeniu działalności kulturalnej, które z jednej strony ustanawiają kompetencję ustawową dla ministra właściwego do spraw kultury i ochrony dziedzictwa narodowego do ustanawiania i przyznawania dorocznych nagród za osiągnięcia w dziedzinie twórczości artystycznej, upowszechniania i ochrony kultury ${ }^{6}$, a z drugiej strony zawierają delegację dla ministra do szczegółowego określenia warunków i trybu przyznawania tych nagród w drodze rozporządzenia ${ }^{7}$. Również nowe przepisy o szkolnictwie wyższym nadają ministrowi prawo do przyznawania nagród za znaczące osiągnięcia w zakresie działalności naukowej, dydaktycznej, wdrożeniowej lub organizacyjnej albo za całokształt dorobku ${ }^{8}$ oraz zawierają upoważnienie dla ministra właściwego do spraw szkolnictwa wyższego i nauki do określenia, w drodze rozporządzenia, szczegółowych kryteriów i trybu przyznawania oraz sposób wypłacania tych nagród, rodzaje osiągnięć i sposób ich dokumentowania, maksymalną liczbę przyznawanych nagród, maksymalną wysokość nagrody oraz wzór wniosku o jej przyznanie, mając na uwadze potrzebę zapewnienia wysokiego poziomu osiągnięć umożliwiających uzyskanie nagrody, sprawnego przebiegu postępowań w sprawie jej przyznania i sprawnego wypłacania oraz adekwatności wysokości nagrody do rangi osiągnięć.

W kontekście powyższego należy zwrócić jeszcze uwagę na nowe przepisy ustawy - Prawo o szkolnictwie wyższym i nauce (art. 364), na mocy których Prezes Rady Ministrów może przyznać nagrodę, po zasięgnięciu opinii powołanego zespołu, za wyróżniające się rozprawy doktorskie, wysoko ocenione osiągnięcia będące podstawą nadania stopnia doktora habilitowanego lub osiągnięcia w zakresie działalności naukowej lub wdrożeniowej. Jednocześnie szczegółowe regulacje w tym zakresie mają zostać sprecyzowane w akcie wykonawczym, którego przepisy powinny określać szczegółowe kryteria i tryb przyznawania nagród, rodzaje osiągnięć i sposób ich dokumentowania, skład i czas trwania kadencji zespołu, jego zadania, sposób ich wykonywania, wysokość wynagrodzenia oraz sposób obsługi i finansowania jego prac, maksymalną liczbę przyznawanych nagród, maksymalną wysokość nagrody oraz wzór wniosku o jej przyznanie. Należy mieć przy tym na uwadze potrzebę zapewnienia wysokiego poziomu osiągnięć umożliwiających uzyskanie nagrody, sprawnego przebiegu postępowań

5 Rozporządzenie Ministra Sportu i Turystyki z 14 listopada 2017 r. w sprawie wyróżnień i nagród pieniężnych za wybitne osiągnięcia sportowe, Dz.U. poz. 2135.

6 Zob. art. 7a ustawy z 25 października 1991 r. o organizowaniu i prowadzeniu działalności kulturalnej, t.j. Dz.U. 2018, poz. 1983.

7 Rozporządzenie Ministra Kultury i Dziedzictwa Narodowego z 24 maja 2012 r. w sprawie warunków i trybu przyznawania dorocznych nagród za osiągnięcia w dziedzinie twórczości artystycznej, upowszechniania i ochrony kultury, Dz.U. poz. 610.

8 Zob. art. 362 ustawy z 20 lipca 2018 r. - Prawo o szkolnictwie wyższym i nauce, Dz.U. poz. 1668. 
w sprawie jej przyznania oraz adekwatności wysokości nagrody do rangi osiągnięć. W związku z tym może rodzić się pytanie, czy uprawnienie Prezesa Rady Ministrów do przyznania nagrody w dziedzinie nauki wynikające z przepisów ustawy - Prawo o szkolnictwie wyższym i nauce oraz projektowane uprawnienie do przyznawania nagród specjalnych za wybitne osiągnięcia naukowe stanowią tę samą okoliczność?

- Przepis, który wskazuje działania Prezesa Rady Ministrów odnośnie do przyznawania nagród specjalnych, proponuje się umieścić na końcu rozdz. V ustawy o Radzie Ministrów, tj. w grupie przepisów, które określają zakres podmiotów obsługiwanych przez Kancelarię Prezesa Rady Ministrów, kierownictwo Kancelarii oraz jej zadania, a także zawierają nakaz powoływania i odwoływania sekretarzy i podsekretarzy stanu w Kancelarii przez Prezesa Rady Ministrów. W związku z tym należy podkreślić, że możliwość przyznawania nagród przez właściwych ministrów nie jest określona w rozdz. VI ustawy o Radzie Ministrów grupującym regulacje określające zakres i zasady działania ministrów. Okoliczności przyznawania nagród za szczególne osiągnięcia naukowe, sportowe czy w zakresie kultury i dziedzictwa narodowego są określone w przepisach kształtujących problematykę prawną tych dziedzin, tj. w ustawach: Prawo o szkolnictwie wyższym i nauce, o sporcie, o organizowaniu i prowadzeniu działalności kulturalnej. Przy tej okazji należy zwrócić również uwagę, że obecnie jedynie przepisy w obszarze szkolnictwa wyższego i nauki określają w sposób szczegółowy okoliczności przyznawania nagród przez Prezesa Rady Ministrów. Natomiast obowiązujące przepisy zarówno ustawy o sporcie odnośnie do przyznawania nagród za wybitne osiągnięcia sportowe, jak i ustawy o organizowaniu i prowadzeniu działalności kulturalnej odnośnie do nagród z zakresu kultury i ochrony dziedzictwa narodowego nie nadają Prezesowi Rady Ministrów prawa do przyznawania nagród.

\section{Ocena kosztów i korzyści}

Niewątpliwie nie jest możliwe wskazanie choćby szacunkowej wysokości nagród specjalnych Prezesa Rady Ministrów przyznawanych w poszczególnych latach. Decyzja o ich przyznaniu ma wynikać bowiem każdorazowo z zaistnienia szczególnie uzasadnionego przypadku, w tym uzyskania wybitnego osiągnięcia naukowego, sportowego lub z zakresu kultury i ochrony dziedzictwa narodowego. Trudno oszacować liczbę takich wydarzeń w danym roku. Niemniej należy zauważyć, że okoliczności, w których ministrowie mają prawo do przyznawania nagród, również mają charakter losowy. Przykładowo liczba nagród za wybitne osiągnięcia sportowe zależy m.in. od liczby miejsc pierwszych, drugich i trzecich zajętych na igrzyskach olimpijskich, igrzyskach paraolimpijskich, igrzyskach głuchych, w mistrzostwach świata i w mistrzostwach Europy oraz od ustanowie- 
nia rekordu świata, a przepisy zakładają ich finansowanie ze środków budżetu państwa z części, której dysponentem jest minister do spraw kultury fizycznej. Środki na nagrody w tym wypadku planowane są w wydatkach budżetowych części 25 na podstawie zapotrzebowania wynikającego $\mathrm{z}$ analizy wykonania wydatków z lat ubiegłych, co pozostaje w związku z progresją wyników sportowych.

Zagrożenie może wynikać $\mathrm{z}$ odmiennego traktowania nagród przyznawanych przez ministrów i Prezesa Rady Ministrów. Zgodnie bowiem z projektem przewiduje się zwolnienie przyznanej przez Prezesa Rady Ministrów nagrody specjalnej z podatku dochodowego od osób fizycznych. Tymczasem w myśl obowiązującego brzmienia art. 21 ust. 1 pkt 132 ustawy o podatku dochodowym od osób fizycznych wolne od podatku dochodowego są przyznane przez krajowe i zagraniczne organy władzy i ich urzędy, w tym jednostki organizacyjne im podległe lub przez nie nadzorowane, oraz krajowe, zagraniczne i międzynarodowe organizacje (instytucje) i ich organy, nagrody za wybitne osiągnięcia z dziedziny nauki, kultury i sztuki oraz z tytułu działalności na rzecz praw człowieka w części przekazanej jako darowizna przez podatników, którzy otrzymali te nagrody, na rzecz instytucji realizującej cele określone w art. 4 ustawy o działalności pożytku publicznego. Przy tym zwolnienie to stosuje się, jeżeli wysokość nagrody przekazanej na rzecz instytucji realizującej cele jest udokumentowana dowodem wpłaty na rachunek bankowy obdarowanej instytucji, a w przypadku nagrody innej niż pieniężna - dokumentem, z którego wynika wartość przekazanej nagrody, oraz oświadczeniem obdarowanej instytucji o jej przyjęciu oraz że nagroda została przekazana najpóźniej do dnia upływu terminu dla złożenia zeznania podatkowego, składanego za rok podatkowy, w którym otrzymano nagrodę.

\section{Podsumowanie - ogólna ocena projektu}

- Projekt ustawy zmierza do umożliwienia Prezesowi Rady Ministrów przyznawania osobom fizycznym, w szczególnie uzasadnionych przypadkach (w tym za wybitne osiągnięcia naukowe, sportowe lub z zakresu kultury i ochrony dziedzictwa narodowego) nagród specjalnych. Jest to projekt, który został zwolniony z obowiązku opracowywania założeń projektu ustaw decyzją Rady Ministrów.

- Według ustalonego poglądu w piśmiennictwie zapis uprawniający Prezesa Rady Ministrów do przyznawania nagrody specjalnej z rezerwy ogólnej budżetu państwa należy uznać za błędny. Chodzi o to, że dla rezerwy ogólnej charakterystyczne jest to, iż w momencie jej uchwalania nie ma jakiegokolwiek wskazania jej przeznaczenia.

- Zastrzeżenia może budzić niedookreślenie zdarzeń, które mogą stanowić przesłankę do przyznania nagrody specjalnej. Wskazane w proponowanej treści przepisu dziedziny, w których Prezes Rady Ministrów mógłby przyznawać te nagrody, mają w istocie niedookreślony charakter. 
- W świetle braku szczegółowych uregulowań co do zasad przyznawania nagród specjalnych przez Prezesa Rady Ministrów mogą rodzić się pytania m.in. odnośnie do trybu postępowania z tymi nagrodami, warunków ich przyznawania, ich wysokości czy podmiotów uprawnionych do zgłaszania osób fizycznych do tych nagród.

- Wątpliwości może budzić umiejscowienie przepisu wskazującego okoliczności przyznawania nagród specjalnych przez Prezesa Rady Ministrów w grupie przepisów dotyczących zadań, kompetencji oraz form organizacyjnych odnoszących się do Kancelarii Prezesa Rady Ministrów.

- Projekt może różnicować pod względem podatkowym osoby mające uzyskiwać nagrody specjalne Prezesa Rady Ministrów wobec osób uzyskujących nagrody od ministrów.

- W związku z tym, że przedmiotowy projekt ustawy, zmierzający do nadania Prezesowi Rady Ministrów uprawnienia do przyznawania w szczególnie uzasadnionych przypadkach nagród specjalnych, rodzi wątpliwości i zastrzeżenia, może warto byłoby rozważyć możliwość dokonania korekty zaproponowanych regulacji, tak aby można było osiągnąć cel stawiany przed tym projektem przy zastosowaniu środków, które byłyby mniej problematyczne. 